\title{
Comments
}

\section{GATT, THE CALIFORNIA BUY AMERICAN ACT, AND THE CONTINUING STRUGGLE BETWEEN FREE TRADE AND PROTECTIONISM}

California and five other states ${ }^{1}$ have statutes which give a preference in governmental contracts to users and supphers of American-made products. Section 4303 of the California Government Code provides that:

The governing body of any political subdivision, municipal corporation, or district, and any public officer or person charged with the letting of contracts for (1) the construction, alteration, or repair of public works or (2) for the purchasing of materials for public use, slall let such contracts only to persons who agree to use or supply only such unmanufactured materials as have been produced in the United States, and only such manufactured materials as have been manufactured in the United States, substantially all from materials produced in the United States.

In 1947, the United States joined with other countries to draft and put into effect the General Agreement on Tariffs and Trade, commonly referred to as GATT, ${ }^{2}$ a multi-nation pact aimed at establishing a cooperative atmosphere in trading among free world countries. GATT's objectives are the elimination of all discriminatory treatment in international commerce and the reduction of tariffs and other trade barriers. ${ }^{3}$ Paragraph 4 of Article III of GATT provides that:

The products of the territory of any contracting party imported into the territory of any other contracting party shall be accorded treatment no less favourable than that accorded to like products of national origin im respect of all laws, regulations and requirements affecting their internal sale, offering for sale, purchase, transportation, distribution, or use. 4

In what is apparently the first reported case to consider a possible conflict between GATT and a state Buy American statute or the federal Buy American Act, ${ }^{5}$ a California district court of appeal in Baldrein-Lima-Hamilton Corp. $v$. Superior Court ${ }^{6}$ stated, in dicta, that the California Buy American statute did

1 Hawam Rev. Laws § 9-23 (1955) ; Mass. Gen. Laws ANn. ch. 7, § 22(17) (Supp. 1962); N.J. Stat. ANN. § 52:33-2 (Supp. 1962); 61 Okra. Stat. ANN. \$ 51 (1959); 71 PURdon's Pa. Stat. ANN. \$ 639 (1962).

2 The provisions of GATT are set out in 61 Stat. Parts (5-6), T.I.A.S. No. 1700 (1947), as amended 62 Stat. (Part 3) 3680, T.I.A.S. No. 1890 (1948). The official text of GATT has also been published by the contracting parties in a series of pamphlets entitled GENERAL AGREEarent on TartfFs and Trade, Basic Instrunients and Selected Documents.

361 Stat. (Part 5) A11, T.I.A.S. No. 1700 (1947).

461 Stat. (Part 5) A18, T.I.A.S. No. 1700 (1947), as amended 62 Stat. (Part 3) 3681, T.I.A.S. No. 1890 (1948). Paragrapl 4 was originally numbered paragraph 2 but was renumbered by the 1948 amendment.

5 Act of March 3, 1933, 47 Stat. 1520, as amended 41 U.S.C. $\$ \$ 10$ (a)-(d) (1958).

$6208 \mathrm{Cal}$. App. 2d 803, 25 Cal. Rptr. 798 (1962) (hearing denied Dec. 19, 1962). Conupare Moore Supply Co. v. City of Abilene, Civil No. 2073, ND. Tex., Jan. 15, 1962, in which the court granted defendant's motion for sunmary judgment in an action brouglit by a disappointed bidder on a contract to sell water pipe to the defendant city. Plaintiff, whose bid had included Belgian-manufactured pipe, attacked the city's award to a higher bidder whose bid was based on the use of American-manufactured pipe. The specifications provided for American-manufactured pipe. The court did not have to consider the clash between GATT and any Buy American statute since, inter alia, it apparently concurred in defendant's argument that the city's purchase fell clearly within paragraph 8(a) of article III of GATT and thus was excepted from the provisions of GATT as a purchase "for governmental purposes." 
conflict with paragraph 4 of Article III of GATT and therefore was superseded under the supremacy clause of the Constitution. ${ }^{7}$

Baldwin and Allis-Chalmers Manufacturing Company had responded to a contract proposal issued by the City and County of San Francisco calling for the submission of sealed bids for furnishing certain equipment to be used in the municipally owned power generating station. The contract proposal contained a "Place of Manufacture" clause which stated: "All materials, supplies and equipment covered by this contract proposal shall be manufactured in the United States, except as otherwise provided in the Government Code of the State of California." Baldwin and Allis each submitted a bid in comphance with the place of manufacture clause, Allis's bid bemg lower. Baldwin submitted another bid based on furnishing certain component parts manufactured outside the Umited States. This bid by Baldwin was the lowest of the three.

The purchaser of supplies for San Francisco, acting on the advice of the city attorney, announced his intention to award the contract to Baldwin on the theory that the place of inanufacture clause, admittedly in the contract proposal because of Section 4303 of the California Government Code, was invalid because superseded by GATT. Allis then petitioned the superior court for a writ of mandate ${ }^{8}$ asking that the municipal officials be compelled to award the contract to it and that they refrain from awarding it to Baldwin. In a inemorandum opinion the superior court held that the place of manufacture clause was invalid under the supremacy clause because superseded by GATT. But the court also held that insertion of the clause in the call for bids defeated the fundamental requirement in awarding public contracts-that the call clearly apprise prospective bidders so as to promote competitive bidding on equal terms. Therefore the court refused to compel the city officials to award the contract to Allis, but it enjoined the officials froin awarding the contract to Baldwin or anyone else. Before findings could be signed or any further proceedings taken in the trial court, Baldwin petitioned for a writ of prohibition to restrain the trial court from taking any further action in Allis's mandamus proceeding, except to deny the writ of mandate. The district court of appeal held that the superior court was not in excess of its jurisdiction and denied the peremptory writ. ${ }^{9}$

After initially deciding that GATT superseded the place of manufacture pro-

7 U.S. Const. art. VI, cl. 2.

8 CAL. CODE Crv. PROC. §§ 1084-87.

9 The court initially decided that because the city officials had charter authority to reject all bids, mandamus would not lie to compel the award to Allis. Though the charter authority was sufficient hasis for this decision, it is possible that the court further justified this result by concluding that the place of manufacture provision was superseded by GATT. Both parties petitioned the California Supreme Court for a hearing-Baldwin, to reverse the district court's affirmance of the injunction preventing the award to Baldwin, and Allis, to attack the trial court's determination that the place of manufacture provision was invalid because superseded by GATT. Allis contended that because of the nature of the proceedings in prohibition, it was precluded from arguing this point before the district court and that the trial court's determination would become the law of the case. In the trial court Allis had presented the case as a problem of competitive bidding procedures rather than as a case involving the Californin Buy American Act and GATT. Letter from counsel for Allis to author, on file in the office of the California Law Review. The supreme court demied both petitions. The city then rejected all bids and advertised for new ones. Both bidders acquiesced in this procedure and the casc was dropped. Letter from counsel for Baldwin to author, on file in the office of the California Law Review. 
visions, the district court went on to conclude that the equipment was for use in the generation of electric power for resale and hence for "use in the production of goods for sale," thereby removing the purchase from the excepting provisions of paragraph 8(a) of Article III of GATT. This conclusion rested on a prior district court of appeal decision ${ }^{10}$ which held that electricity was a commodity which, like other goods, could be manufactured, transported and sold. The city attorney of San Francisco and the court relied in part on interpretations by the attorney general of California which take the position that, except where either the California Buy American Act or GATT is made inapplicable by its own excepting provisions, GATT supersedes the state statute.11

It should be noted that in addition to the six states with specific Buy American statutes, ${ }^{12}$ thirty-three other states require by statute that preferences be given in government contracts to manufacturers, suppliers, and users wlio are residents of the respective states. ${ }^{13}$ To the extent that competitive bidding develops between a resident of a particular state with such a statute and a foreign bidder from a country which is a party to GATT, the effect of the local preference statute is similar to a Buy American statute in subordinating foreign competition to domestic. Either interpretation-that GATT supersedes the state statutes, or that the state laws are controlling-will have far-reaclimg effects, both national and international, on those who sell to state and local governmental agemes. It seems apppropriate to examine the situation closely to determine if Baldwin correctly resolved the conflict. ${ }^{14}$

THE ENACTMENT OF GATT

GATT is an executive agreement entered into by the United States pursuant to the authority granted the President under the Reciprocal Trade Agreements Act of $1934 .{ }^{15}$ That act authorized the President to enter into foreign trade agreements for the purpose of expanding American exports. He was empowered to reduce the then-existing tariff rates by up to fifty per cent in exchange for similar concessions and to prevent, through a set of trade mles, impairment of those (1905)

10 Terrace Water Co. v. San Antonio Light \& Power Co., 1 Cal. App. 511, 82 Pac. 562

1140 Ops. Cal. Atr'y Gen. 65 (1962); 38 Ops. Cal. Atr'y Gen. 192 (1961); 37 Ops. CaL. AtT'y Gen. 156 (1961); 36 Ops. CaL. AtT'y Gen. 147 (1960); 34 Ops. CaL. ATT'y Gen. 302 (1959).

12 See note 1 supra.

${ }^{13}$ For a list of states requiring such, see note 59 infra. The statutes have been upheld in the few contests in which they have been challenged. See Schrey v. Allison Steel Mfg. Co., 75 Ariz. 282, 255 P.2d 604 (1953); Denver v. Bossie, 83 Colo. 329, 266 Pac. 214 (1928); State v. Senatobia Blank Book \& Stationery Co., 115 Mass. 254, 76 So. 258 (1917); Tribune Co. v. Barnes, 7 N.D. 591, 75 N.W. 904 (1898). The local preference statutes, however, would seem to be invalid under the commerce clause. Cf. Baldwin v. G.A.F. Seelig, Inc., 294 U.S. 511 (1935).

14 In addition to preference statutes, state discrimination against foreign goods can be in the form of discriminatory marking and placard requirements, taxation, inspection laws, and hicensing. For a discussion of these practices, see Note, 12 STAN. L. Rev. 355 (1960).

1548 Stat. 943 (1934), as amended, 19 U.S.C. $\$ 1351$ (1958). 
tariff reductions. ${ }^{16}$ That authority, with some modification in detail, ${ }^{17}$ has been periodically renewed, ${ }^{18}$ the latest expression being embodied in the Trade Expansion Act of $1962 .^{19}$ GATT is not a treaty; it has never been submitted to nor ratified by the Senate. Its provisions, however, have been considered by Congressional committees, usually during the course of hearings on the several Trade Agreements Extension Acts. ${ }^{20}$ In the 1955 Act, section 3(a)(1)(A) provided that: "[T] he enactment of the Trade Agreements Extension Act of 1955 shall not be construed to determine or indicate the approval or disapproval by the Congress of the executive agreement known as the General Agreement on Tariffs and Trade." ${ }^{21}$ Whatever hesitations the members of Congress may have had concerning GATT apparently no longer exist, or have been minimized, since the Trade Expansion Act of 1962 does not contain a similar provision. ${ }^{22}$

The constitutionality of the delegation of authority to the President to conclude international agreements under the Reciprocal Trade Agreements Act of 1934 has been supported on the basis: (1) that it meets the standard of permissible congressional delegation of any type of authority or, (2) that the President's power over foreign affairs permits a delegation with far broader stand-

16 "The Tariff Act of 1930 is amended by adding at the end of title III the following: Sec. 350(a). For the purpose of expanding foreign markets for the products of the United States (as a means of assisting in the present emergency in restoring the American standard of living, in overcoming domestic unenployment and the present cconomic depression, in increasing the purchasing power of the Anerican public, and in establishing and maintaining a better rclationship among various branches of American agriculture, industry, mining, and commerce) by regulating the admission of foreign goods into the United States in accordance with the characteristics and needs of various branches of American production so that foreign markets will be made available to those branches of American production which require and are capable of developing such outlets by affording corresponding market opportumities for foreign products in the United States, the President, whenever he finds as a fact that any existing duties or other import restrictions of the United States or any foreign country are unduly burdening and restricting the forcign trade of the United States and that the purpose above declared will be promoted by the means hereinafter specified, is authorized from time to time (1) To enter into foreign trade agreenients with foreign governnents or instrumentalities thereof; and (2) To proclaim such modifications of existing duties and other import restrictions, or such additional import restrictions, or such continuance, and for such minimum periods, or existing custons or excise treatment of any article covered by foreign trade agrecments, as are required or appropriate to carry out any foreign trade agreement that the President has entered into hereunder. No proclamation shall be made increasing or decreasing by more than 50 per centum any existing rate of duty or transferring any article between the dutiable and free lists ...." 48 Stat. 943-44 (1934).

17 The period of authority of the President to enter such agreements has varied from three to five years; the maximun percentage in tariff reduction allowed has also fluctuated.

1872 Stat. 673 (1958); 69 Stat. 162 (1955); 63 Stat. 698 (1949); 59 Stat. 410 (1945); 57 Stat. 125 (1943).

1976 Stat. 872 (1962), 19 U.S.C.A. § 1821 (Supp. 1963).

20 Hearings on H.R. 5550 Before the House Committee on Ways and Means, 84th Cong., $2 \mathrm{~d}$ Sess. (1956); Hearings on H.R. 1 Before the House Comnittee on Ways and Means, 84th Cong., 1st Sess. (1955); Hearings on H.R. 1 Before the Senate Committee on Finance, 84th Cong., 1st Sess. (1955); Hearings on H.R. 1612 Before the Senate Committee on Finance, 82d Cong., 1st Sess. (1951); Hearings on H.R. 1211 Before the Senate Committee on Finance, 81st Cong., 1st Sess. (1949). See also StafF for the Subcomenirtere on Foreign Trade Policy of the House Commattee on Ways and Means, Compendium of Papers on United States Foreign Trade Policy (1958); House Committee on Ways and Means and Senate Committee on Finance, 83d Cong., 1st Sess., Statements on H.R. 5495 and Summary of TestTMONY ON RELATEd Provistons OF H.R. 4294 (1953).

2169 Stat. 163 (1955), 19 U.S.C. \& 1351 (1958).

2276 Stat. 872 (1962), 19 U.S.C.A. \$ 1821 (Supp. 1963). 
ards than would be required with regard to domestic matters. ${ }^{23}$ Since GATT is not a treaty ratified by the Senate, there has been some question whether it should be accorded the same efficacy under the supremacy clause as a treaty. The court in Baldwin, relying on the doctrine developed in United States v. Belmont ${ }^{24}$ and United States $v$. Pink, ${ }^{25}$ that international agreements negotiated and proclaimed by the President are "treaties" within the meaning of the supremacy clause, concluded that GATT superseded inconsistent state law. Since the 1957 defeat of the Bricker Amendment, the furor over the executive agreement has diminished, ${ }^{26}$ and the substantial weight of authority appears to support the Belmont-Pink doctrine, ${ }^{27}$ at least to the extent that the executive agreement will override inconsistent state legislation. ${ }^{28}$ The Court of Customs and Patent Appeals in Star-Kist Foods, Inc. v. United States ${ }^{29}$ included trade agreenents under the Belmont-Pink rule, and a territorial court has specifically given GATT the same efficacy as a treaty. ${ }^{30}$

One provision in GATT seems, on its face, to support an inference that GATT was not intended to conie within the supremacy clause. Paragraph 12 of Article XXIV of GATT provides: "Each contracting party shall take such reasonable measures as may be available to it to assure observance of the provisions of this Agreement by the regional and local governments and authorities within its territory." 31 This could be interpreted as only requiring the federal government to attempt, by negotiations and persuasion, to have the states repeal inconsistent laws. If this were the correct interpretation, the effect would presumably be to preserve inconsistent state laws despite the supremacy clause. Article XXIV, however, was intended to apply only to those contracting parties under whose constitutions international agreements cannot supersede inconsistent legislation of political subdivisions. ${ }^{32}$ It seems likely in light of the Belmont-Pink doctrine

23 See, e.g., Kefauver, The Trade Agreements Act and the Constitution, 17 TENN. L. Rev. 846 (1943); Sayre, The Constitutionality of the Trade Agreements Act, 39 Colum. L. Rev. 751 (1939); Note, U.S. Participation in GATT, 61 Colum. L. Rev. 505 (1961).

24301 U.S. 324 (1937).

25315 U.S. 203 (1942).

20 Cardozo, The Authority in Internal Law of International Treaties: The Pink Case, 13 Syracuse L. Rev. 544, 553 (1962).

27 See. e.g., Cardozo, The Authority in Internal Law of International Treaties: The Pink Case, 13 Sxracuse L. Rev. 544 (1962); McDougal \& Lans, Treaties and Congressional-Executive or Presidential Agreements: Interchangeable Instruments of National Palicy (pts. 1-2), 54 Yale L.J. 181, 534 (1945). But see, e.g., Borchard, Shall the Executive Agreement Replace the Treaty, 53 YALE L.J. 664 (1944); Borchard, Treaties and Execative Agreements-A Reply, 54 YaIE L.J. 616 (1945).

28 Cf. United States v. Guy W. Capps, Inc., 204 F.2d 655 (4th Cir. 1953) (executive agreement that was not authorized by Congress and that contravened provisions of existing federal statute held void, and contract based thereon unenforceable), aff'd on other grounds, 348 U.S. 296 (1955).

2947 C.C.P.A. (Customs) 52 (1959).

30 A post-GATT statute, which made it unlawful for any person to sell, offer, or expose for sale any imported chicken shell eggs of foreign origin unless a placard bearing the words "We Sell Foreign Eggs" printed in legible boldface letters of a size not less than three inches in height was displayed in a conspicuous place where the customers entering could see it, was struck down as a violation of the supremacy clause because it was contrary to the "national treatment" provisions of Article III of GATT. Territory of Hawaii v. Ho, 41 Hawaii 565 (1957).

3161 Stat. (Part 5) A67-68, T.I.A.S. No. 1700 (1947), as amended 62 Stat. (Part 2) 2013, T.I.A.S. No. 1765 (1948).

32 Letter of Feb. 26, 1957, from Dep't State Legal Adviser to Acting Attorney General of Hawaii, cited in Note, 12 Stan. L. Rev. 355, 373-74 (1960). 
that if called upon to render a decision, the United States Supreme Court would accord GATT the power of the supremacy clause.

GATT was originally designed as a temporary measure pending the adoption of the Havana Charter which would have established the International Trade Organization. ${ }^{33}$ The governments of Australia, Belgium, Canada, France, Luxemburg, the Netherlands, the United Kingdom, and the United States undertook to apply GATT soon after the agreement was drawn instead of waiting for the completion of procedures required for the agreement to enter into force definitively. ${ }^{34}$ The Protocol of Provisional Application ${ }^{35}$ was signed in Geneva on October 30,1947 . The signatories agreed to apply provisionally on and after January 1 , 1948, parts I and III of GATT without qualification, and part II of GATT "to the fullest extent not inconsistent with existing legislation." 36 It was only through the Protocol of Provisional Application that the provisions of GATT became binding upon the Umited States. It is by virtue of the Protocol that GATT is operating today-GATT has never been definitively accepted..$^{37}$ Article $\mathrm{III}$ of GATT, the focus of the discussion herein, is contained in part II. The provisions of article III, therefore, were accepted by the United States and the other signatories to the Protocol only to the extent not inconsistent with legislation existing as of October 30, 1947. The United States reaffirmed its acceptance of part II of GATT to the same himited extent wlien, in 1955, it signed a protocol amending certain parts of GATT. ${ }^{38}$

The attorney general of California recognized that the United States accepted GATT through the Protocol of Provisional Application, ${ }^{39}$ but concluded that the Protocol did not change the national treatment provisions of paragraph 4 of arti-

3317 Dep'T STATE BuLc. 1050-51 (1947). The final Charter was adopted in Havana in 1948. It was introduced in Congress in 1949 but was not voted upon. See H.R.J. Res. 14, 71, 236, 81st Cong., 1st Sess. (1949) ; 96 Cong. Rec. 2988 (1950). In December 1950 the Administration announced that it would not resubmit the Charter for congressional approval. 23 DEp' $T$ State BuLc. 977 (1950). The International Trade Organization (ITO) failed when the United States, which had been its real sponsor, elected not to participate. It has been suggested that the inauguration of the Marshall Plan with its emphasis on Western Europe, replaced ITO in the United States' focus. Also, it was felt by the United States business community that the Charter was weighted against the United States. The more flexible GATT met with greater approval. The death of the Havana Charter resulted in the present existence of GATT. Muramadad, The Legal Framework of Worid Trade 20-22 (1958).

34 Article XXVI (2) of GATT provided that the original agreement should be deposited with the Secretary-General of the United Nations and article XXVI (3) declared that each government accepting the Agreement should deposit an instrument of acceptance with the Secretary-General. The Agreement, under article XXVI (5) (a), was to enter into force definitively, as among the governments which accepted it, on the thirtieth day following the day on which instruments of acceptance had been deposited on behalf of those signatory governments which accounted for eighty-five per cent of the total exterual trade of all signatories.

3561 Stat. (Part 6) A2051, T.I.A.S. No. 1700 (1947).

36 Ibid.

37 Cf. 3 U.N. Treaty SerIes Cum. Index $286-87 ; 2$ id., at $216-17 ; 1$ id., at 313 ; 301-441 U.N. Treaty SERres; Declaration of Provisional Accession of Argentina to the General Agreement on Tariffs and Trade, 442 U.N. TREATY SERIES 302, 304 (1962). Agreeing that the acceptance through the Protocol limited the application of Article III is MUHAMMAD, op. cit. supra note 33, at 167-68. A United States Department of State official has recognized that one of the two great handicaps under which GATT operates is that it is in force only provisionally and can only operate subject to legislation existing as of October 30, 1947. Willoughby, The Annecy Conference on Tariffs and Trade, 21 DeP'T State Bull. 774, 778 (1949).

38 [1957] 2 U.S.T. \& O.I.A. 1767, 1859, T.I.A.S. No. 3930.

3936 Ops. CaL. ATT'y GeN. 147 (1960). 
cle III which were a "mandatory duty upon each of the nations accepting the provisions of GATT." ${ }^{40}$ This interpretation fails to appreciate that the nations accepting the provisions of GATT did so only through the Protocol and that the Protocol made the national treatment provisions a "mandatory duty" only to the extent not inconsistent with legislation existing as of October 30, 1947.

If the phrase "existing legislation" were intended by its draftsmen to include state legislation, then GATT does not supersede the California Buy American Act and other state preference statutes existing as of October 30, 1947. On the other hand, if that phrase is limited to federal legislation only, then under the supremacy clause GATT would supersede the state statutes. There is scant authority on this point, but there are arguments supporting each interpretation. After the decision not to resubmit the Havana Charter to Congress ${ }^{41}$ and in anticipation. of the eventual definitive acceptance of GATT, the State Department officials who represented the United States in the GATT negotiations prepared for Congress a memorandum of inconsistent existing legislation which would have to be repealed. ${ }^{42}$ The memorandum considered only federal legislation. ${ }^{43}$ The absence of any reference in the memorandum to state legislation supports two opposite conclusions. First, it could be inferred that state legislation was not to be superseded by GATT since Congress would only be concerned with repealing federal legislation and was only interested in learning which existing federal acts would have to be repealed. On the other hand, if the purpose of the memorandum was to inform Congress of all laws that would have to be repealed, the memorandum might mdicate an intent for GATT to override existing state legislation, since, if the opposite conclusion were intended, the State Department would have included imconsistent state Jaws in its extensive meinorandum. The United States, in other international agreements, has used language equivalent to the phrase "existing federal legislation." 44 The use of particular language or the indication of a particular intent in one international agreement, however, can provide little support for an argument to imply such language or intent in others.

In Guaranty Trust Co. v. United States ${ }^{45}$ the Supreme Court stated that: "Even the language of a treaty wherever reasonably possible will be construed so as not to override state laws or to impair rights arising under them."46 In Guaranty a New York bank sought to plead the statute of limitations in an action brought by the United States as assiguee under an executive agreement with the Soviet Government of claims recoverable in the United States. The Court held that though the right to plead the statute could have been curtailed by the agreement, there was nothing in it purporting to enlarge the assigned rights in the hands of the United States when the Soviet Government had not pursued its claims within the prescribed statutory period. Similarly, a court might find it possible to construe an ambiguous phrase such as "existing legislation" to include state legislation so as not to override state law. The cases cited in Guaranty in

40 Id. at 149.

41 See note 33 supra.

42 This memorandum is set out in Hearings on H.R. 1612 Before the Senate Committee on Finance, 82 Cong., 1st Sess. 1195 (1951).

43 The federal Buy American Act was not listed as inconsistent with GATT. Ibid.

44 See, e.g., Protocol to Treaty of Friendship, Commerce and Navigation with the Federal Republic of Germany, Oct. 29, 1954, [1956] 2 U.S.T. \& O.I.A. 1904-05, T.I.A.S. No. 3593.

45304 U.S. 126 (1937).

$46 I d$. at 143. 
support of the quoted language are susceptible of an interpretation, however, which would tend to weaken the effect of that language. ${ }^{47}$ In particular the reliance on Nielsen $v$. Johnson ${ }^{48}$ seems to conflict with the policy statement enunciated in Guaranty. In holding that a state inheritance tax discriminating against non-resident alien heirs of a resident decedent violated a treaty with Denmark the Court in Nielsen stated: "[A]s the treaty-making power is independent of and superior to the legislative power of the states, the meaning of treaty provisions so construed [liberally] is not restricted by any necessity of avoiding possible conflict with state legislation and when so ascertained must prevail over inconsistent state enactments." ${ }^{49}$ Both Guaranty and Nielsen were cited with approval in a later Supreme Court decision. ${ }^{50}$ Considered together, they negate the effect that each separately would lend as support for either of the two interpretations of "existing legislation." If a treaty can be interpreted in two ways, one restrictive as to the rights that may be claimed under it and the other liberal, the courts generally prefer the latter. ${ }^{51}$ This rule probably will apply to an executive agreeinent such as GATT also. ${ }^{52}$ To the extent an interpretation that "existing legislation" includes federal legislation only, the trading possibilities in the United States for the foreign signatories to GATT are broadened. Since such an interpretation would be less restrictive of the rights that could be claimed under GATT, it could find support in this liberal rule of treaty construction.

When the resolution of a case hinges on a determination of whether state laws are included in "existing legislation," the court, in the absence of stronger authority on either side, may take into consideration the respective policy arguments, viz., free trade or domestic protection. The enormity of the considerations ${ }^{63}$ suggest that the eventual determination should be decided on a national level through the pohtical process, and most courts would probably subscribe to this view. Yet when a court must decide a case, in the absence of a legislative determination, the policy arguments could be an underlying basis of the decision.

If foreign countries are able to sell more freely in the United States by virtue of a policy which allows them to compete equally with domestic firms, the United States is given greater leverage in attempting to obtain an increased market through lowering or eliminating tariffs and other trade barriers abroad. Such a

47 Todok v. Union State Bank, 281 U.S. 449, 454 (1930) ; Nielsen v. Johnson, 279 U.S. 47, 52 (1929) ; Dooley v. United States, 182 U.S. 222, 230 (1901) ; Haver v. Yaker, 76 U.S. (9 Wall.), 32, 34 (1869) ; United States v. Arredondo, 31 U.S. (6 Pet.) 691, 748 (1832).

48279 U.S. 47 (1929).

49 Id. at 52 .

50 United States v. Pink, 315 U.S. 203, 230-31 (1942).

51 Bacardi Corp. v. Donjenech, 311 U.S. 150 (1940); Factor v. Laubenheimer, 290 U.S. 276 (1933); Nielsen v. Johnson, 279 U.S. 47 (1929); Jordan v. Tashiro, 278 U.S. 123 (1928); Asakura v. Seattle, 265 U.S. 332 (1924); Hauenstein v. Lynham, 100 U.S. 483 (1879); Shanks v. DuPont, 28 U.S. (3 Pet.) 242 (1830).

52 See notes 24-30 supra and acconipanying text.

53 For example, the Tariff Conmission, in proceedings to establish the peril point of various imports usually considers the following factors: conditions, causes, and effects relating to competition between foreign industries and United States industries producing like or competitive articles; employment in the United States; profit levels; prices; wages; the use of productive facilities in the domestic industry; whether such use will be lessened because of the proposed reduction; the state of obsolescence of equipment in the domestic industry; the nature and extent of the change in employment that might result; and whether thcre will be an idling of productive facilities. See W.S. Surrey, Legal Problems to be Encountered in the Operation of Trade Expansion Act of 1962, 41 N.C.L. REv. 389, 393 (1963). 
program not only reduces United States surpluses but also allows the United States consumer to obtain certain items at a cheaper price. Increased foreign exports may be the lifeblood of many friendly smaller countries; interdependence economically can create stronger pohtical ties and simultaneously result in a reduction in foreign aid as the emerging nations develop through the greater international trading potential. ${ }^{54}$

Such a trade program would inevitably force a relocation among certain segments of our national economy, but a governmental adjustment assistance program could alleviate this hardship. ${ }^{55}$ The preference statutes, in effect, provide a subsidy to a small segment of the population at the expense of the other taxpayers through increased costs of governmental operation where governmental agencies are forced to purchase from domestic sources at increased prices. It has been suggested that the statutes invite collusion among the preferred segment of the economy since suppliers knowing of their preference can increase their bids accordingly. ${ }^{56}$ Then, too, to the extent that many of the Buy American statutes were enacted during the depression years, ${ }^{57}$ it can be argued that whatever support could be foimd at that time for legislation designed to stimulate a broken economy, or at least stem the downward acceleration, is considerably weaker today.

On the other hand, a court might interpret legislative maction in repealing Buy American laws as an indication that conditions prevalent at the time of enactment are still deeined to exist. It is certaiuly inportant to the continued profitable operation of some manufacturers or suppliers that their preference be continued.58 Perhaps a court faced with this decision would be influenced by a knowledge that a determination that GATT superseded a state Buy American Act might result in adverse economic repercussions in the immediate area in which the court was sitting.

If it were concluded that "existing legislation" did include state legislation and that consequently GATT did not supersede such legislation existing as of October 30, 1947, still, Buy American and local preference statutes enacted subsequent to October 30,1947 , would be invalid. ${ }^{59}$ That some states could vahily

54 45 Dep't State BuLI. 247-49 (1961). The argument is also raised that a balance-ofpayments deficit, not the result of our present foreign trade program, could be removed or lessened through increased exports. $I d$. at 249-50. The extensive aspects of the balance-ofpayments problem preclude discussion in this Comment.

55 Trade ExPansion ACT of 1962, 76 Stat. 883 (1962), 19 U.S.C.A. \$\$ 1909-91 (Supp. 1963). Where national security is concerned, special provisions of the Trade Expansion Act of 1962 are apphicable. 76 Stat. 876 (1962), 19 U.S.C.A. \$§ 1861-62 (Supp. 1963).

50 Rydland, $A$ "Bity Michigan" Purchasing Policy?, 18 Unrv. of Mich. Papers In Pub. Adomin. 44 (1956).

57 E.g., federal Buy American Act (1933) ; Pennsylvania (1929) ; California (1933); New Jersey (1934). See notes 1 and 6 supra.

58 But see text accompanying note 55 supra.

59 National preference statutes existing as of October 30,1947 ; California (1933) ; Hawaii (1941); New Jersey (1934); Pennsylvania (1929). National preference statutes enacted subsequent to October 30, 1947: Massachusetts (1958); Oklahoma (1959). Local preference statutes existing as of October 30, 1947: Arizona (1928) ; Colorado (1919); Georgia (1937); Idaho (1939); Tllinois (1937); Iowa (1927); Louisiana (1928); Maryland (1939); Michigan (1929); Mississippi (1932); Missouri (1939); Montana (1923); New Mexico (1939); North Carolina (1931); North Dakota (1935); Oregon (1943); South Carolina (1935); South Dakota (1939); Virginia (1928); Washington (1933); West Virginia (1935); Wisconsin (1929); Wyoming (1931). Local preference statutes enacted subsequent to October 30, 1947: Alabama (1961); Alaska (1949); Arkansas (1959); Florida (1961); Kansas (1953); Maine (1954); Minnesota (1959); Nevada (1951); Rhode Island (1950); Texas (1957). 
enforce Buy American statutes while others could not might be an element considered by a court in concluding that "existing legislation" did not include state legislation.

\title{
II
}

\section{THE GATT EXCEPTION CLAUSE}

If it is determined that GATT supersedes the state acts, it still must be determined whether the particular purchase is exempted from GATT by virtue of the exception clause of article III. ${ }^{60}$ Paragraph $8(\mathrm{a})$ of Article III of GATT provides that:

\begin{abstract}
The provisions of this article shall not apply to laws, regulations or requirements governing the procureinent by governmental agencies of products purchased for governmental purposes and not with a view to coinmercial resale or with a view to use in the production of goods for commercial sale.61 Difficulties are encountered in interpreting two terms in the exception clause: (1) "goods" and (2) "governmental purposes."
\end{abstract}

The district court of appeal in Baldrein decided that the purchase of electrical equipment for use in generating electric power was the purchase of a product for "use in the production of goods for sale" and fell outside the exception clause of article III. ${ }^{62}$ The decision intimated that the determination of whether a governmental purchase was to fall within the article III exception was to be made by looking at prior cases which have characterized items such as electricity as either goods or services. ${ }^{63}$ The California attorney general opimons have generally followed such a procedure. ${ }^{64}$ The cases that have made these characterizations, however, have not done so in the context of an international agreement such as GATT. They have been concerned with such problems as the resolution of a contract action, ${ }^{65}$ the determination of a tax liability, ${ }^{66}$ and the declaration of the constitutionality of the sale by the federal government of electrical energy..$^{67}$

Again there is little relevant material from which the intent of the framers of GATT can be gleaned. Annex I, ad Article XVII, paragraph 2 of GATT states: "The term 'goods' is limited to products as understood in commercial practice, and is not intended to mclude the purchase or sale of services." ${ }^{08}$ The French

6061 Stat. (Part 5) A19, T.I.A.S. No. 1700 (1947), as amended 62 Stat. (Part 3) 3681, T.I.A.S. No. 1890 (1948). Paragraph 8(a) was originally numbered paragraph 5 but was renumbered by the 1948 amendment. Article III was subsequently renumbered article IV, see [1957] 2 U.S.T. \& O.I.A. 1768, 1807, T.I.A.S. No. 3930, but it is usually still referred to as article III, and it will he so cited herem.

61 Ibid.

62 See text accompanying note 10 sitpra.

63 Ibid.

64 See 34 Ops. Car. AtT'y Gen. 302 (1959). 562 (1905).

65 See, e.g., Terrace Water Co. v. San Antonio Light \& Power Co., 1 Cal. App. 511, 82 Pac.

66 E.g., Curry v. Alabama Power Co., 243 Ala. 53, 8 So. 2d 521 (1942).

67 Ashwander v. Tennessee Valley Authority, 297 U.S. 288 (1936).

6861 Stat. (Part 5) A89, T.I.A.S. No. 1700 (1947). Annex I contains the interpretive notes. Article XXXTV of GATT provides that the annexes to the agreement are made an integral part of it. 61 Stat. (Part 5) A75, T.I.A.S. No. 1700 (1947). Article XVII concerns State-Trading Enterprises but contains an exception clause nearly identical to paragraph 8(a) of article III. See 61 Stat. (Part 5) A53, T.I.A.S. No. 1700 (1947). 
version of GATT provides no assistance in the defining of "goods." 69 In the French version the word corresponding to "goods" is "marchandises" 70 and that French word is defined, generally, as encompassing those things which can be moved from one place to another without deterioration. ${ }^{71}$ Electricity would seem to qualify under this definition. In considering the relative efficacy of GATT and the California Buy American Act, a court influenced by the policy arguments discussed above which favor free trade would probably have no difficulty in determining that in the context of the international agreement electricity was "goods."

An equally difficult interpretive problem exists with the term "governmental purposes."72 A decision that a purchase is not for a "governmental purpose" places it within the national treatment requirement of GATT. Is the purchase of electrical equipment to be used in a municipally-owned power generating station a purchase for a "governmental purpose"? The only inaterial discovered which indicates to any extent the drafters' intent seems to imply that the term not be given a restricted meaning. ${ }^{73}$ If such a limited interpretation were given, it would seem that even the federal Buy American Act was inconsistent with GATT. Yet, the federal Buy American Act was not among those listed in the memorandum of inconsistent laws prepared for Congress by the State Department. ${ }^{74}$ Accordingly, a conclusion could be drawn that the exception clause is intended to relate to any governmental purchase except perhaps to those occasions when a governmental agency is clearly engaging in competitive commercial activity. ${ }^{75}$

On the other hand, an analogy drawn from the international law doctrine of sovereign immumity, by which the courts of one country consider granting or denying immunity to an instrumentality of another country, would lead to the opposite conclusion. The trend in this doctrine has been toward the so-called "restrictive" theory which recognizes immunity only with regard to public acts (jure imperii) but not with respect to private acts (jure gestionis). ${ }^{76}$ A state acts privately when, "in view of the needs of the commumity, it acquires and possesses property, [enters into] contracts, becomes a creditor or debtor, carries on commerce, or reserves to itself monopolies on the conduct of services of general utility." "77 Simce it is acting as a private individual, engaging in busimess with and competing against other private individuals, it is treated as one when disputes

69 Article XXVI (2) of GATT provides that both the French and English versions shall be considered authentic. 61 Stat. (Part 5) A69, T.I.A.S. No. 1700 (1947). See United States v. Percheman, 32 U.S. (7 Pet.) 51 (1833) ; United States v. Arredondo, 31 U.S. (6 Pet.) 691 (1832).

70 GATT, part II, art. III (5), 61 Stat. A1376, T.I.A.S. No. 1700 (1947).

71 "Marchandise": ce qui est meuble et objet de commerce. 4 LITTRE, DictionnaIRE DE LA Langue Francarse 2000 (1960). "Meuble": Terme de jurisprudence. Biens nueubles, les choses qui peuvent se transporter d'un lieu dans un autre sans deterioration. 5 id. at 208. The French cases which deal with "marchandises" might shed further light on the scope of that term; no researcl, lrowever, has been done in that area for this Comment.

72 See note 60 sicpra and accompanying text.

73 See note 42 sitpra and accompanying text.

74 Ibid.

75 E.g., New York v. United States, 326 U.S. 572 (1946) (state engaged in sales of bottled mineral water from state owned springs).

70 Alien, The Postiton of Foreign States Before National Courts, Chuefly in ConTINENTAL EUROPE 301 (1933). Letter of Acting Legal Adviser of Dep't of State to Dep't of Justice, May 19, 1952, 26 Dep'x State BuLL. 984 (1952).

77 S.A. Chemin De Fer Liegeois-Luxembourgeois v. Etat Neerlandais, Cour de Cassation, 1903 Pasicrisie belge I.294. See generally, Draft Convention and Comment on Competence of Courts in Regard to Foreign States, 26 AMr. J. INT'L L. SuPP. 451 (1932). 
arise, and in those situations it is not cloaked with immunity. The United States has subscribed to this view. ${ }^{78}$ Since a governmental agency acting in such a private capacity would be stripped of its immunity and suffer the liability of the private individual, it is arguable that it should, in fairness, be treated as a private individual for beneficial purposes also. Therefore it should not be burdened with the requirement of purchasing domestic items at higher prices. Under such reasoning the effects of the California Buy American Act could provide the basis for a definition of "governmental purposes" that would not include a Baldwin situation.

A less appropriate analogy could be drawn from the "old"79 domestic sovereigu immunity doctrine, distinguishing between governmental and proprietary functions..$^{80}$ But because the courts have himited that test to tort situations only, ${ }^{81}$ there have been non-tort cases in which a governmental agency, acting in the traditional "proprietary" capacity, has been found to be engaging in a legitimate governmental function. ${ }^{82}$ The use of these cases would tend to broaden "governmental purposes," therefore bringing more purchases within the GATT exception clause. Agam, as with other aspects of the GATT-Califorma Buy American Act conflict, the imclination toward free trade or protectionism will be of sigunificance in the selection of the case law that a court will look to in interpreting "governmental purposes."

\section{III}

\section{THE BUILT-IN LIMITATIONS OF THE CALIFORNIA BUY AMERICAN ACT}

Even if it should be decided that GATT does not supersede the California Buy American Act or that a particular purchase is not within the national treatment requirements of GATT because of the exception clause, it is still possible to limit the effect of the California statute. Sucl a limitation would be in consonance with a belief that free trade is preferred, or, at least, that the state's interference in foreign affairs should be kept to a minimum. As a preliminary step,

78 Letter of Acting Legal Adviser of Dep't of State to Dep't of Justice, May 19, 1952, 26 Dep'T State BuLL. 984, 985 (1952). For a discussion of this policy, see authorities cited in Bishop, InTERAationaI LAw 570 n.164 (2d ed. 1962). In matters such as granting or denying immumity to a foreign governinent, the courts will normally follow the directions of the Executive Department. The Baja California, 324 U.S. 30 (1945). When public acts are questioned, foreign governments are still granted immunity from jurisdiction by United States courts under the act of state doctrine. Banco Nacional de Cuba v. Sabbatino, 84 S. Ct. 923 (1964).

79 The California Legislature in 1963 enacted a comprehensive statutory scheme which now places the emphasis on the nature of the particular act or activity out of which the suit arises rather than on the nature of the agency responsible for that act or activity. All Califoriua agencies will generally be liable to suit where the liability arises from the "ministerial" acts of their employees; all will be immune where the liability arises from a "discretionary" act. See CAL. Gov'T CODE $\$ \S 810-996.6$. See generally Van Alstyne, Governmental Tort Liability: Political Lazmaking in a Statutory Milieu, 15 STAN. L. Rev. 163 (1963).

80 See discussion in Muskopf v. Corning Hosp. Dist., 55 Cal.2d 211, 359 P.2d 457, 11 Cal. Rptr. 89 (1961).

8 I E.g., Brush v. Comm'r, 300 U.S. 352 (1937).

82 E.g., City of Pasadena v. Railroad Comm'n, 183 Cal. 526, 530, 192 Pac. 25, 27 (1920). California agencies have always been amenable to suit in contract actions, e.g., Souza \& McCue Constr. Co. v. Superior Court, 57 Cal. 2d 508, 370 P.2d 338, 20 Cal. Rptr. 634 (1962) ; Touchard v. Touchard, 5 Cal. 306 (1855), on a theory approximating the "restrictive" theory of sovereign immunity in international law, supra notes 79-81. 
it is necessary to consider the interrelationship of two sections in the California Buy American Act and to decide what effect is to be given to each.

Section 4301 of the California Government Code provides in part that: "This article [referring to sections 4300-05] does not apply to nuaterials which are of a class or kind which are not, or which are manufactured from materials which are not, produced in the United States ...." Whether materials are of a class or kind not produced in the United States is a question of fact which according to the California Attorney General is initially to be resolved by the purchasing official responsible for the decision. ${ }^{83}$ Section 4303 of the California Government Code provides that contracts shall be let only to such persons who agree to use or supply "such manufactured nuaterials as have been manufactured in the United States, substantially all from materials produced in the United States." The interpretation of these two sections by the Attorney General, developed through several opinions, ${ }^{84}$ is that they are read together to provide that in pubhic contracts a preference should be given only to those persons who agree to use or supply articles that are manufactured in the United States and that are constructed "substantially all" from materials produced in the United States. However, the preference applies only if all the materials are of a class or kind which, in fact, are produced in this country. ${ }^{85}$ The effect of these opinions has been to limit the application of the Buy American Act. Under this interpretation the "substantially all" test is applied only to those articles which could be produced entirely from domestic sources. Such an interpretation would give no preference to a domestic manufacturer who was forced to use the shightest amount of materials not produced in the United States, but would provide a preference for the manufacturer who could use materials all of which were available in the U.S. but who elected to substitute few enough foreign materials to leave him within the "substantially all" test. For example, assume that a piece of electrical generating equipment needed for a inunicipal power system can be supplied with a certain flexibility among the components. The equipment of competitor $A$ is composed of parts all of which are produced in the United States. Competitor $A$ elects, however, to manufacture his finished product using an iteen which he purchases abroad. This item constitutes ten per cent of the value of his finished product ("substantially all" from U.S. nuaterials). But competitor B's equipment requires a small component part, constituting only five per cent of the total value, which is not produced in the United States, and which he must, therefore, purchase abroad. Both finished products meet the required specifications. Under the attorney general's interpretation, competitor $A$ is entitled to a preference, and competitor $B$ is not, even though $B$ 's product is ninety-five per cent American while $A$ 's is only ninety per cent.

It is not difficult to arrive at this interpretation when only the plain language of the statutes is considered. But in light of the purpose of the Buy American Acts, which presumably are intended to encourage purchasing froin doniestic, as opposed to foreign, sources, the interpretation seems to be erroneous-the result of hteral reading of poor statutory drafting. Not coincidentally, this language in Sections 4301 and 4303 of the California Government Code is identical to lan-

8339 Ops. Cal. Atr'y Gen. 112, 113 (1962); 37 Ops. Cal. Atr'y Gen. 156, 157 (1961).

8439 Ops. Cal. AtT'y Gen. 112 (1962) ; 38 Ops. Cal. AtT'y Gen. 192 (1961) ; 37 Ops. Cal. Atr'y Gen. 156 (1961); 27 Ops. Cal. Atx'y Gen. 52 (1956).

8540 OPS. CAL. ATT'y Gen. 65 (1962). 
guage contained in the federal Buy American Act. ${ }^{86}$ The congressional debates and the passage of the federal act coincided with the passage of the California statute, and Senator Hiram Johnson of California introduced the federal act in the Senate. ${ }^{87}$ It seems reasonable to infer that the legislative intent was the same for both acts. A 1937 Comptroller General opinion ruled that the federal statute taken as a whole nidicated "that the intent is to protect not only the domestic miner or producer but also the domestic manufacturer," and accordingly held that articles manufactured in the Umited States of rubber not available in the United States had to be purchased rather than similar articles manufactured abroad. ${ }^{88}$ This position was reversed in 1949, the Comptroller General holding that "where the naterials used in the nuanufacturing process are not produced in the United States in sufficient and reasonably available commercial quantities and of a satisfactory quality, the permission to procure the finished product extends to articles nianufactured abroad as well as to those manufactured in the United States." 80 As a result of that ruling Congress amended the Buy American Act to indicate a specific intent that domestic manufacturers were entitled to a preference even though the finished product consisted of materials less than "substantially all" of which were produced in the United States.90

Whether under the California Buy American Act the preference should be given only to manufacturers who only use parts produced or mined in the United States or whether it should also be extended to domestic manufacturers who must use some items not produced or mined in the United States, the act's apphication can still bo limited by giving "substantially all" a rational meaning. Presumably, if the end product contained forty-nine per cent foreigu materials, the article would not be manufactured "substantially all" from materials produced in the United States. ${ }^{21}$ Interpreting the phrase "substantially all" to mean containing

86 Act of March 3, 1933, 47 Stat. 1520, as amended 41 U.S.C. $\$ \S 10 a-d$ (1958). Section 10a provides: "Notwithstanding any other provision of law, and unless the head of the department or independent establishment concerned shall determine it to be inconsistent with the public interest, or the cost to be unreasonable, only such unmanufactured articles, materials, and supplies as have been mined or produced in the United States, and only such manufactured articles, materials, and supplies as have been manufactured in the United States substantially all froin articles, materials, or supplies mined, produced, or manufactured, as the case may bc, in the United States, shall be acquired for public use. This section shall not apply with respect to articles, materials, or supplies for use outside the Urited States, or if articles, materials, or supplies of the class or kind to be used or the articles, materials, or supplies from which thcy are manufactured are not mined, produced, or manufactured, as the case may be, in the United States in sufficient and reasonably available commercial quantities and of a satisfactory quality." For a thorough discussion of the federal Buy American Act, see Gantt \& Speck, Domestic v. Foreign Trade Problems in Federal Government Contracling: Buy American Act and Excutive Order, 7 J. PuB. L. 378 (1958); Knapp, The Buy American Act: A Review and Assessment, 61 Colvar. L. REv. 430 (1961).

87 Gantt \& Speak, supra note 86, at 378-79.

8817 Decs. Comp. Gen. 244 (1937).

8928 DeCs. CoMp. GEN. 591, 593 (1949).

9063 Stat. 1024 (1949), 41 U.S.C. § 10d (1958).

01 On December 17, 1954, by Executive Order 10582, a preference under the federal Buy American Act was to be allowed domestic manufacturers whose articles contained foreign items constituting fifty per cent of the total cost of the article. Gantt \& Speck, supra note 86, at 398-99. The applieation of the federal Buy American Act should not necessarily be a guide for the California statute, in this respect, since the federal act allows the agency head to disregard the provisions of the Act in those situations where the cost differential between the domestic and the foreign article is unreasonable and where the granting of the preference to 
no significant amount of foreign ingredients probably best reconciles sections 4301 and 4303 while, at the same time, it preserves the essential purpose of the preference. By so limiting the statute, the state is keeping any interference in foreign affairs to a minimum. On the basis of California Attorney General opinions, ${ }^{92}$ it appears that in the absence of any further legislative guidance the burden of making these determinations rests on the shoulders of the purchasing officials.

\section{CONCLUSION}

Whether the United States' acceptance of GATT through the Protocol of Provisional Application invalidated those state Buy American Acts existing as of October 30,1947, depends on whether "legislation existing as of October 30, 1947 ," which was not to be superseded by GATT, includes state legislation. This determination should be made only after a careful examination of the current validity of the policy reasons behind GATT and the Buy American Acts. The policy reasons may also be important, assuming that GATT supersedes the preference statutes, in defining the scope of the GATT exception clause. If GATT does not supersede the California Buy American Act and if it is felt that sounder pohicy favors free trade, the California Act could, through its own provisions, be narrowly applied. Thus the State's interference in the conduct of national foreign policy would be minimized. ${ }^{93}$

Patrick S. Hobin

the domestic manufacturer would be inconsistent with the public interest. Act of March 3, 1933, 47 Stat. 1520, as amended 41 U.S.C. $\$ 10$ a (1958). The California statute does not have a similar provision. See CAL. Gov'T Code \$ 4303.

9239 Ops. Cal. ATT'y Gen. 112, 113 (1962); 37 Ops. Car. ATT'Y Gen. 156, 157 (1961).

93 In Baldwin the court found that in addition to GATT a "most-favored-nation" provision in a treaty of friendship, commerce, and navigation with Japan covered the foreign materials mcluded in Baldwin's low bid. 208 Cal. App. 2d 803, 820, 25 Cal. Rptr. 798, 809 (1962). The Umited States is a party to many such treaties. See, e.g., Treaties IN ForCE, DEP'T SIATE PUB. 7481 (1963) 5, 11, 15, 17, 46, 49. To the extent that the parties to the treaties are also contracting parties of GATT, the treaties generally provide that "they shall not preclude action by either party which is required or specifically permitted by GATI during such time as either party is a contracting party to GATT." See, e.g., Treaty of Friendship, Commerce and Navigation with the Federal Republic of Germany, Oct. 29, 1954, art. XXIV (4), [1956] 2 U.S.T. \& O.I.A. 1839, 1864-65, T.I.A.S. No. 3593; Treaty of Friendship, Commerce and Navigation with Japan, Apr. 2, 1953, art. XXI (3), [1953] 2 U.S.T. \& O.I.A. 2063, 2079, T.I.A.S. No. 2863. These treaties therefore have the same effect as GATT on the Buy American Acts. There might be a different result with respect to the relationship of the Buy American Acts to bilateral treaties between nations who are not parties to GATT. E.g., Treaty of Peace, Friendship, Commerce and Navigation with Bolivia, May 13, 1858, art. III, 12 Stat. 1003, 1004, T.S. No. 32 (1863). See also Trade Agreement with Iceland, Aug. 27, 1943, Art. I, 57 Stat. 1075, 1078, E.A.S. No. 342 (1943). 